\title{
Gyógyszertranszporterek szerepe a központi idegrendszerben
}

\author{
Erdő Franciska dr. ${ }^{1}$ - Temesszentandrási-Ambrus Csilla ${ }^{2}$ - Beéry Erzsébet dr. ${ }^{2}$ \\ ${ }^{1}$ Pázmány Péter Katolikus Egyetem, Információs Technológiai és Bionikai Kar, Budapest \\ ${ }^{2}$ Solvo Biotechnológiai Zrt., Budaörs
}

\begin{abstract}
Bár a vér-agy gát jelenlétét az emlősszervezetekben már a XX. század elején felismerték, pontos szerkezetét, illetve a benne található gyógyszertranszporter fehérjéket csak az utóbbi évtizedekben azonosították. A központi idegrendszer védelmét biztosító ATP-kötő kazettatranszporter pumpafehérjék mellett fontos szerepet játszanak az idegrendszer múködésében a solute carrier transzporterek is, amelyek a táplálék- és energiaellátást biztosítják, illetve a metabolizmus során „eltakarító” funkciót is betöltenek. Az összefoglaló közlemény áttekintést ad az idegrendszerben előforduló főbb transzporter fehérjetípusokról, sejttípusonkénti lokalizációjukról, illetve a vizsgálatukra szolgáló főbb módszerekről. A közlemény második felében különböző neurodegeneratív betegségek és a patológiájukkal összefüggésbe hozható transzporter fehérjék kerülnek bemutatásra. Mindezek fényében olyan új terápiás stratégiák kerülhetnek a figyelem középpontjába, amelyek a jelenleg gyógyíthatatlan betegségek esetében jelenthetnek majd megoldást. Orv. Hetil., 2016, 157(10), 370-378.
\end{abstract}

Kulcsszavak: membrántranszporterek, vér-agy gát, neurodegeneratív betegségek, központi idegrendszer

\section{Role of drug transporters in the central nervous system}

\begin{abstract}
Although the presence of blood-brain barrier in the mammalian organisms was discovered in the early 1900s, its precise structure and the drug transporter proteins localized in the blood-brain barrier were identified only in the last decades. Beside the ATP-binding cassette transporter proteins responsible for the protection of the brain, the Solute Carrier transporters play also an important role in the function of the central nervous system by its feeding, energy supply and cleaning function during the metabolism. This review provides an overview on the main types of transporters located in the brain, on their localization in different cell types and the main techniques for their investigation. In the second part of this article various neurodegenerative disorders and the pathology-related transporter proteins are presented. In the light of recent experimental results new therapeutic strategies may come into the focus of research for the treatment of disorders currently without effective therapy.
\end{abstract}

Keywords: membrane transporters, blood-brain barrier, neurodegenerative diseases, central nervous system

Erdö, F., Temesszentandrási-Ambrus, Cs., Beéry, E. [Role of drug transporters in the central nervous system]. Orv. Hetil., 2016, 157(10), 370-378.

(Beérkezett: 2015. december 28.; elfogadva: 2016. január 19.)

\begin{abstract}
Rövidítések
$\mathrm{A} \beta=$ béta-amiloid protein; $\mathrm{ABC}=\mathrm{ATP}$-binding cassette transporter; AIDS $=$ acquired immunodeficiency syndrome; ALS $=$ amyotrophiás lateralsclerosis; ANLSH = astrocyta-neuron laktát sönt hipotézis; ATP = adenozin-trifoszfát; BCRP = breast cancer resistance protein; $\mathrm{Caco} 2=$ caucasian colon adenocarcinoma cell line; $\mathrm{CSF}=$ cerebrospinal fluid CTL $=$ kolintranszporter; DAT $=$ dopamintranszporter; EAAT $=$ excitáns aminosav-transzporter; ECF $=$ extracellular fluid; FDA $=$ Food and
\end{abstract}

Drug Administration; GABA = gamma-aminovajsav; GAT = GABA-transzporter; GLAST = glutamát-aszpartát transzporter; GLT = glutamáttranszporter; GLUT = glükóztranszporter; GlyT = glicintranszporter; hCMEC/D3 = human cerebral microvascular endothelial cell line; HIV = human immunodeficiency virus; HMG-CoA = 3-hydroxy-3-methylglutaryl-coenzyme A; $\mathrm{KO}=$ knockout; LLC-PK = porcine kidney epithelial cell line; $\mathrm{MBEC}=$ mouse brain endothelial cell line; MCT $=$ monokarboxilát-transzporter MDCK $=$ Madin-Darby canine 
kidney cell line; $\mathrm{MRP}=$ multidrug resistance protein; $\mathrm{OAT}=$ organikus aniontranszporter; OATP $=$ organikus aniontranszporter polipeptid; OCT $=$ organikus kationtranszporter; PEPT $=$ peptidtranszporter; $\mathrm{P}-\mathrm{gp}=$ permeabilitási glikoprotein; $\mathrm{QSAR}=$ quantitative structure activity relationship; $\mathrm{RBEC}=$ rat brain endothelial cell line; SERT = szerotonintranszporter; SLC = solute carrier; SSRI = szelektív szerotonin reuptake inhibitor; Tau $\mathrm{T}=$ taurintranszporter

\section{Gyógyszertranszporterek szerepe a molekulák központi idegrendszeri megoszlásában}

Az agynak és a gerincvelőnek fontos tulajdonsága, hogy a szervezet többi részétől elkülönült keringéssel rendelkezik. Az erre vonatkozó megfigyeléseket elsőként Edwin Goldman (dél-afrikai német tudós) írta le 1909ben. Patkányokon végzett kísérletei során a véráramba adott festékanyag megfestette a szervezet minden részét, kivéve az agyat és a gerincvelőt. Ebből arra a következtetésre jutott, hogy az agyban és a gerincben található mikroerek valamilyen speciális permeabilitási tulajdonsággal rendelkeznek. Mint az késóbb igazolódott, a vér-agy gát és a vér-gerinc gát mikroereit burkoló endothelsejtek sokkal szorosabban kapcsolódnak egymáshoz, mint a szervezet más területein levő kapillárisok endothelsejtjei, ezáltal megakadályozva a paracelluláris transzportot. A szervezetben található egyéb kapillárisokkal ellentétben, amelyek viszonylag szabad anyagáramlást tesznek lehetôvé a sejtek között és a sejteken keresztül, az agyi kapillárisok endothelsejtjeinek hézagmentes illeszkedése két nagyságrenddel kisebb átjárhatóságot biztosít. Az endothelsejtek közötti szoros sejtkapcsolatokat "tight junction"-nek (zonula occludens) nevezzük. A vér-agy gát barrier funkciójához a szoros sejtkapcsolat mellett az is hozzájárul, hogy az endothelsejtek abluminális oldala a bazális membránnal érintkezik, amelynek kettőződésében pericyták foglalnak helyet. Továbbá a kapillárisokat az astrocyták végtalpai fedik be - agyi területenként változó mértékben - , ily módon is akadályozva a szabad diffúziót. A vér-agy gát struktúráját az 1 . ábra mutatja be vázlatosan.

Ugyanakkor az agykamrákat burkoló epithelsejtek és a hozzájuk kapcsolódó kapilláris endothelsejtréteg ettől eltérô szerkezetet mutat (2. ábra). Ebben az esetben a „tight junction”, szoros kapcsolat a choroidalis epithelsejtek között található. Az így felépülő anatómiai struktúra a vér-liquor gát, amelynek múködése eltér a vér-agy gáttól, ahogyan azt a későbbiekben látni fogjuk.

A különböző molekulák centrális hatásának kifejlődéséhez szükség van arra, hogy ne csak átjussanak a vér-agy gáton, hanem kelló ideig az agyszövetben tartózkodjanak. Ezt befolyásolják a membrántranszporter fehérjék, amelyek szubsztrátjaikat többnyire az agy védelmében kifelé (efflux transzporterek), mások pedig az agyszövetbe befelé (uptake transzporterek) pumpálják.

\section{ABC (ATP-binding cassette) és SLC (solute carrier) transzporterek szerepe a vér-agy gátban}

Az agyi endothelsejtek génállományának 10-15\%-át transzporterek génjei teszik ki, ami jól jelzi e szállítófehérjék fontosságát. Az idegrendszeri múködéshez nem szükséges, illetve azt kifejezetten gátló anyagok kiszúrése és a szükséges anyagok mennyiségének szabályozása az efflux transzporter pumpák, az ATP-kötő kazetta (ABC) -transzporterek feladata. Az ABC-transzporterek alkotják a fehérjék egyik legnagyobb családját. Az ABC-fehérjék többsége aktív membránpumpa, amelyek ATP-energiájának felhasználásával a koncentrációgradiens ellenében képesek anyagokat szállítani a membránon keresztül. Besorolásukat rokon szerkezeti felépítésük, valamint az a molekuláris mechanizmus teszi lehetővé, amellyel az ATP energiáját múködésükre fordítják. A pumpákkal ellentétben a karrierek közvetlenül nem képesek az ATP, illetve a fény energiájának hasznosítására. Szerepük a passzív (gradiens szerinti) transzport, illetve a pumpák által kiépített iongradiensek terhére végzett (gradienssel szembeni) transzportfolyamatok elősegítése.

Az agyi hajszálerekben az SLC szállítófehérje-család látja el a központi idegrendszert a múködéséhez szükséges tápanyagokkal. E tápanyagok lehetnek cukrok, ketontestek, aminosavak, lipidek, vitaminok, ásványi sók, metabolikus prekurzorok, peptidek, fehérjék. Az agyi endothelsejtek számos ilyen transzportert expresszálnak: az aminosavtranszportban részt vevő SLC3 és SLC7 család tagjait (például L típusú aminosav-transzporter 1 ), a glükózt transzportáló SLC2-A2 (GLUT-1), a glutamáttranszportban részt vevő SLCl család tagjait vagy az SLC15 (proton/oligopeptid transzporter - PEPT), az SLCl6 (monokarboxilát-transzporter - MCT), az SLC21 (organikus aniontranszporterek - OAT), az SLC22 (organikus anion/kation transzporter - OCT), valamint az SLC44 (kolintranszporter - CTL) család tagjait [1].

A vér-agy gáton különböző ionpumpák révén aktív iontranszport is zajlik $\left(\mathrm{Na}^{+} / \mathrm{K}^{+}\right.$-ATP-áz, $\mathrm{Na}^{+} / \mathrm{K}^{+} / \mathrm{Cl}^{-}$ -transzporter, $\mathrm{Na}^{+} / \mathrm{H}^{+}$-antiporter, $\mathrm{H}^{+}$-ATP-áz).

A vér-agy gát efflux transzporterei (ABC-transzporterek) amellett, hogy különböző xenobiotikumok bejutását regulálják a vérból az agyba, a neurotranszmitterek és metabolitok szintjét is szabályozzák a központi idegrendszerben [2]. Az ABC-transzporterek családjába tartozó ABCBl, ismertebb nevén P-glikoprotein (P-gp) játssza a legfontosabb szerepet ezekben a folyamatokban. A P-gp a lipidoldékony xenobiotikumoknak, mint a vinca alkaloid citosztatikumok, antibiotikumok, antiepileptikumok vagy a HIV-proteázinhibitorok széles tárházát képes kipumpálni a keringésbe [3]. A mellrákrezisztencia-fehérje (ABCG2, BCRP) a P-gp transzporterrel együttmúködve, mint két „kapuőr”, nagyon sikeresen védelmezik a központi idegrendszert. Széles körú 


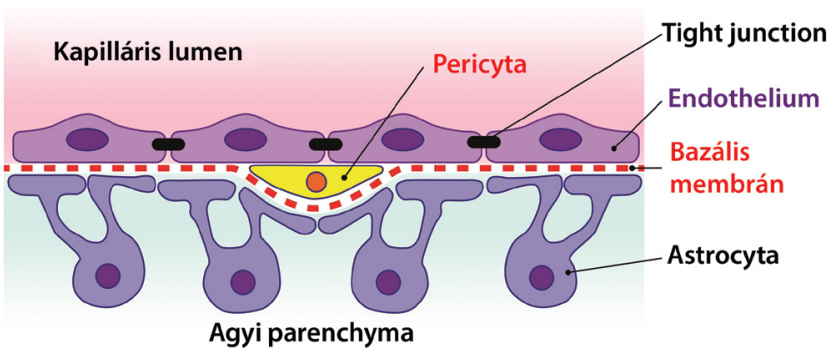

1. ábra

Az agyszövetet az agyi mikrokeringéstől elválasztó vér-agy gát sematikus felépítése

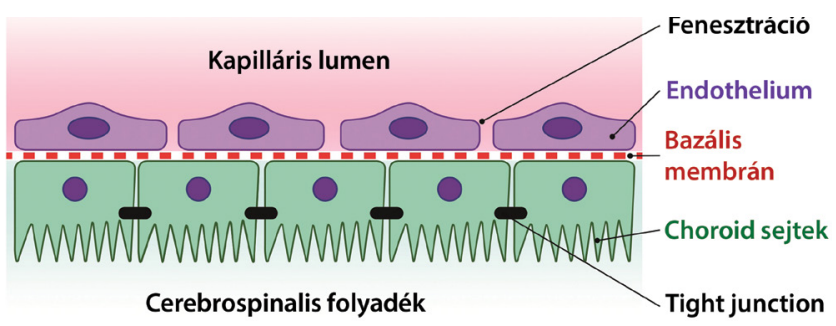

2. ábra

Az agykamrákat burkoló vér-liquor gát sematikus felépítése

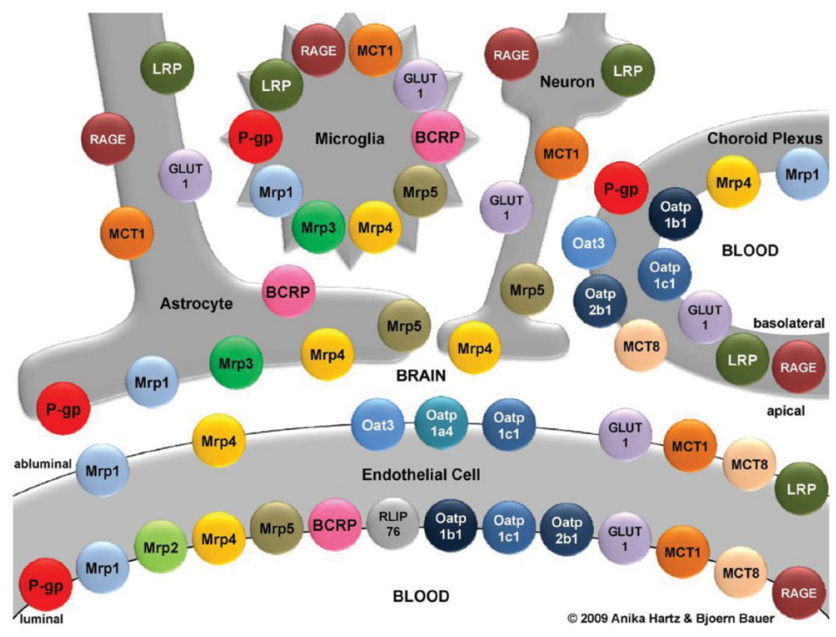

3. ábra

A proteinszinten kimutatott transzporter fehérjék térbeli és sejtszintủ lokalizációja a neurovascularis egységben

$\mathrm{BCRP}=$ breast cancer resistance protein GLUTl $=$ glucose transporter-1; LRP $=$ low-density lipoprotein receptor-related protein; $\mathrm{MCT}=$ monocarboxylic acid transporter; $\mathrm{Mrp}=$ multidrug resistance protein; Oat $=$ organic anion transporter; Oatp $=$ organic anion transporting protein $; \mathrm{P}-\mathrm{gp}=\mathrm{P}$-glycoprotein RAGE $=$ receptor for advanced glycation end products; RLIP76

= Ral-binding protein-1 (Neuwelt és munkatársai 2011-es [11]

közleményéből a szerzők és a folyóirat engedélyével)

szubsztrátfelismerésük és átfedő szubsztrátspecifitásuk révén ezek a fehérjék, amelyek az összes fiziológiai barrierben megtalálhatóak, a szervezetben nagy kapacitású drogtranszporthálózatot alkotnak. Ez a hálózat - az immunrendszerrel rokon vonásai révén - a szervezet kemoimmunitási-védelmi hálózatának részeként is értelmezhetô [4].

A vér-agy gát multidrog rezisztenciafehérjéi (ABCC alcsalád, MRP-k) fóleg leukotriéneket, glutationkonju- gált vegyületeket pumpálnak az endothelsejtekból vissza a vérbe, megakadályozva ezzel az agyba való bejutásukat [5]. További vér-agy gát efflux pumpák az organikus anionok, a szerves savak, urémiás toxinok és a neurotranszmitterek (úgymint a glutamát, szerotonin és kinurénsav) eltávolításában vesznek részt [6].

Neurofarmakológiai szempontból kihívást jelent a centrális támadáspontú gyógyszermolekulák átjuttatása a vér-agy gáton, mivel az itt lokalizálódó efflux transzporterek a különböző gyógyszerek átjutását erősen korlátozzák. Az átjuttatásra kidolgozott módszerek - mint amilyen a vér-agy gát tranziens nyitása, terápiás nanorészecskék alkalmazása, farmakonok kémiai módosítása, specifikus receptorok felhasználása - ellenére sem tekinthető a probléma megoldottnak.

$\mathrm{Az}$ ember várható élettartamának növekedésével párhuzamosan a neurodegeneratív megbetegedések száma világszerte növekvő tendenciát mutat. A neurofarmakológiai piac mára a gyógyszeripar egyik legjelentősebb szegmensévé vált. A molekuláris neurofarmakológia fejlődéséhez és új gyógyszerfejlesztési stratégiák kidolgozásához nagyban hozzájárul a neuronalis hálózatok, a glia-neuron kölcsönhatások molekuláris feltérképezése, a neurokémiai kölcsönhatások, receptorok és transzporterek mind pontosabb megismerése [7].

\section{Neuronalis és gliális transzporterek}

A gliális és neuronalis SLC szállítófehérjék egyebek mellett fontos szerepet játszanak e sejtek metabolizmusában. $\mathrm{Az}$ astrocyták membránjában található glutamát vagy excitatorikus aminosav-transzporter (excitatory amino acid transporter - EAAT, SLCl) család tagjai a glutamát/ GABA (gamma-aminovajsav) glutaminciklus kulcsfehérjéi. Fiziológiásan a felszabadult glutamátot fóleg az astrogliákon található EAATl (GLAST) és EAAT2 (GLT1) fehérjék távolítják el a szinaptikus résből. $\mathrm{A} \mathrm{Na}^{+} / \mathrm{K}^{+}$ egyensúly felborulása a sejtben a glutamáttranszporter múködésének megfordulásához vezethet, excitotoxikus hatást okozva ezzel. Neurodegeneratív betegségekben (például: amyotrophiás lateralsclerosis - ALS) során a neuronok pusztulásának ez az egyik kiváltó oka [8,9]. Agyunk a metabolikusan legaktívabb szervünk. A gliasejtek és neuronok membránjában található facilitatív GLUT3 (SLC2A3), illetve GLUT1 (SLC2A1) fehérjék a glükóz felvételét teszik lehetővé [10]. A direkt glükózfelhasználás mellett a neuronalis aktivitás energiaigényének fedezésére a gliasejtek membránjában található monokarboxiláttranszporter-család (MCT, SLC16) fehérjéi, az MCT1 (SLC16Al) és MCT4 (SLC16A4) alternatív energiaforrásokat, ketontesteket, piruvátot, laktátot juttatnak az extracelluláris térbe. A neuronok MCT2 fehérjék segítségével felveszik ezeket (astrocyta-neuron laktát sönt hipotézis - ANLSH).

A vér-agy gátban, illetve a központi idegrendszer különböző sejttípusaiban található főbb ABC- és SLC- 
traszportereket a 3. ábra mutatja be sematikus formában [11].

Más SLC-fehérjék kulcsfontosságúak a szinapszistípustól függő jelátvitelben a megfelelő társuló gliális transzporterekkel együtt. Astrocytákban leírtak GABA (1-es, 2-es és 3-as típusú GABA-transzporterek - GAT13), glicin (GlyTl), monoamin (dopamintranszporter DAT; noradrenalintranszporter - NET; szerotonintranszporter - SERT), hisztamin- és taurin- (TauT) transzport fehérjéket is [12-14].

$\mathrm{Az}$ idegsejtek neurotranszmittertranszportereinek alapvetően két típusát különböztetjük meg, a membrántranszportereket (katecholamin, dopamin, noradrenalin; GABA, glicin, glutamát és szerotonin membrántranszport fehérjéket) és a szekretorikus vesiculákba transzportáló fehérjéket (vesicularis biogén amin, glutamát, gátló aminosav-transzporter fehérjék). A neurotranszmitter transzporterek közül a monoamintranszporterek számos vegyület célpontjai. A kokain a preszinaptikus dopamintranszportert (DAT) gátolja, a következményes dopaminszint emelkedésével fejti ki hatását. A methylphenidat szintén a dopamin visszavételét (reuptake) gátolja, az amfetamin e hatása mellett még a dopaminfelszabadulást is segíti $[15,16]$.

A monoamintranszporterek depresszió kezelésében betöltött szerepe igen jelentős, hiszen a jelenleg használt antidepresszánsok döntő többsége a monoamintranszporterek gátlásán keresztül fejti ki terápiás hatását. A szerotonin szinaptikus résből való visszavételét gátolják a különböző szelektív szerotonin reuptake inhibitorok (SSRI). A szerotonerg szerotonin-noradrenalin reuptake inhibitorok és szerotonin-noradrenalin-dopamin reuptake inhibitorok általánosan használt antidepresszánsok.

\section{Vizsgálati módszerek}

A gyógyszerfejlesztés során ma már alapvető követelmény a gyógyszertranszporterekkel való kölcsönhatás vizsgálata, amely fokozottan igaz a központi idegrendszeri támadáspontú hatóanyagokra. Több szempontból lehet fontos a transzporter-kölcsönhatás felderítése a vér-agy, illetve vér-liquor gát szintjén.

1. Fontos tudni, hogy a központi támadáspont esetében a vizsgált molekula eléri-e a hatás helyén a megfelelő koncentrációt.

2. Perifériás támadáspontú anyagok esetén pedig azt kell tisztázni, hogy bejut-e a vegyület az agyba, s fejt-e ott ki nemkívánatos mellékhatást.

Mindezen folyamatok vizsgálatára in vitro, ex vivo (in situ), in vivo és in silico farmakokinetikai módszerek állnak rendelkezésre.

Számos in vitro vér-agy gát modell használatos, amelyek lehetnek humán vagy állati agyi endothelsejt-astrocyta primer kokultúrák (RBEC, MBEC stb.), vagy immortalizált endothelsejt-sejtvonalak (hCMEC/D3), illetve polarizált epithelialis sejtvonalak, mint például a kutyavese-eredetű Madin-Darby canine kidney (MDCK) és ten- gerimalac-eredetú LLC-PK (porcine kidney) sejtvonalak vagy a humán intestinalis eredetú Caco-2 sejtvonal.

A sejtvonalak transzfektálhatók, hogy az adott vizsgálni kívánt transzporter fehérjét fokozott mértékben expresszálják, s így a vad típusú kultúrából nyert permeabilitási adatokkal összehasonlítást végezhetünk. A primer tenyészeteken a transzporter szubsztrátok, illetve gátlószerek ismert gátlószerrel, illetve szubsztráttal való kombinációban vizsgálhatók.

Az alábbiakban a transzporter-kölcsönhatások in vitro vér-agy gát modellekben történő vizsgálatára mutatunk be néhány példát.

Gao és mtsai a taxol, mint jól ismert P-gp szubsztrát transzportját vizsgálták Caco sejteken. Az apicalistól a basolateralis és az ellentétes irányú transzportot értékelték inhibitorok jelenlétében és hiányában [17]. Moreno-Sanz és mtsai [18] Bcrp-t overexpresszáló MDCKII sejtvonalon vizsgálták zsírsav-amidohidroláz-gátlók penetrációját. Minocha és mtsai [19] szintén MDCKII sejteken tanulmányozták a P-gp- és Bcrp-moduláció hatásait. Immortalizált humán endothelsejtvonalon (hCMEC/D3) is történtek vizsgálatok többféle transzporter-kölcsönhatás irányában [20].

A vér-agy gát anatómiai felépítése szempontjából relevánsabb a primer endothelsejt, illetve endothel-astrocyta-pericyta kokultúrák alkalmazása [21]. A primer endothelsejt-kultúrák származhatnak sertésből [22], patkányból [23], egérből [24], szarvasmarhából [25], hogy csak néhány gyakran alkalmazott fajt említsünk.

Az agyi penetrációt (amelyet transzporterek is regulálnak) ex vivo is vizsgálhatjuk in situ agyi perfúzió módszerével [26]. Az agyi perfúziós módszer mind lassan, mind pedig gyorsan penetráló vegyületek esetében használható. A módszer kivitelezése úgy történik, hogy altatott állaton (többnyire patkányon vagy egéren) az arteria carotis communist kipreparáljuk és az arteria carotis externát ligatúrával elzárjuk. Ezután a tesztanyagot tartalmazó oxigenizált fiziológiás oldatot az arteria carotis internán keresztül perfundáljuk. Végül az agyat analízis céljából eltávolítjuk és az anyagfelvételt meghatározzuk.

E módszer alkalmazására mutatunk be most néhány példát.

Seleman és mtsai a heroinnak és metabolitjainak P-gp kölcsönhatását vizsgálták in situ agyi perfúziós módszerrel [27]. Ugyanezt a technikát alkalmazták professzor Sugiyama és mtsai aromatázinhibitorok P-gp és BCRP interakciójának vizsgálatára [28]. Szintén a Sugiyamacsoport tanulmányozta a pitavastatin, rosuvastatin, taurocholate és ochratoxin A agyi penetrációját vad típusú és OATPla4 knockout egereken [29] in situ agyi perfúzióval.

Míg az in situ agyi perfúzió az agyi uptake-re vonatkozóan ad információt, addig az agy/plazma koncentráció arány, amelyet agyhomogenátumból, illetve vérmintából határoznak meg szisztémás kezelést követően [30], a megoszlásra vonatkozóan jelent információt. Azonban egyik megközelítés sem alkalmas a farmakológiailag ak- 
tív, fehérjéhez nem kötött formában lévő molekulák farmakokinetikai profiljának $\left(\mathrm{C}_{\max }\right.$, fél életidő, koncentráció-idő görbe alatti terület) meghatározására.

A transzporterregulált agyi penetráció vizsgálatát in vivo módszerekkel is végezhetjük. Két megközelítés lehetséges. Az egyik a tesztanyag koncentrációjának liquorban történő meghatározására irányul [31, 32]. Ez tulajdonképpen a vér-liquor gát vizsgálatára alkalmas módszert jelenti. Mintát vehetünk in vivo vagy post mortem az agykamrák valamelyikéből, a subarachnoidalis térből, illetve a cisterna magnából. Valamennyi esetben szabad koncentrációkat tudunk mérni.

A másik megközelítés esetén az agyszövet sejt közötti állományában (ECF) lévő szabad koncentrációkat tudjuk meghatározni, ehhez a megfelelö technika az in vivo mikrodialízis [33, 34]. A mikrodialízis-kísérletek alapját képező, félig áteresztő membránnal ellátott mikrodialízis-prób vagy szonda tetszőleges agyi régióba, illetve az agykamrákba is beültethető. Egy állaton több prób beültetésére is van lehetőség, ezáltal párhuzamosan meg tudjuk határozni például a liquorban, illetve egy specifikus agyi régióban a tesztanyag koncentrációit.

Az agyi transzporter-kölcsönhatások in vivo vizsgálatára mutatunk be most néhány példát.

A Margareta Hammarlund-Udenaes vezette svéd kutatócsoport agyi mikrodialízissel vizsgálta mind az agyszöveti ECF, mind pedig az oldalkamrai liquor (CSF) cefadroxilkoncentrációit probenecid - mint OAT, OATP és MRP inhibitor - jelenlétében és hiányában [35] patkányokon. Nagaya és mtsai majmokon végzett kísérleteikben hasonlították össze a mikrodializátumokban, illetve a ciszternális liquorban mérhető anyagkoncentrációkat P-gp szubsztrátok esetén [36]. Shen és mtsai az intravénásan adott topotecan agyi penetrációját vizsgálták dualprób mikrodialízissel. Az egyik próbot az agyi parenchymába (ECF), a másikat pedig az cerebrospinalis folyadékba (CSF) helyezték vad típusú, mdrla/b, bcrpl, illetve kettős knockout (KO) egereken. Vizsgálták továbbá a koncentrációszinteket gefitinib, mint P-gp- és Bcrp-gátló, és topotecan együttes alkalmazása esetén. Érdekes megfigyelést tettek, miszerint a transzporterfehérjéket nem expresszáló KO egerek esetén az ECF/ plazma koncentráció arány ellentétesen változott, mint a $\mathrm{CSF} /$ plazma koncentráció arány (idő-koncentráció görbe alatti területek aránya) a vad típushoz hasonlítva. Míg a CSF-ben a gátlás hatására csökkent, addig az ECF-ben a gátlás hatására növekedett a topotecan koncentrációja. Ugyanezt tapasztalták, amikor a transzporterek gátlását kémiai úton, gefitinibbel érték el. Mindez arra utal, hogy a vér-agy gátban, illetve a vér-liquor gátban a P-gp és BCRP transzporterek pumpafunkciója ellentétes irányú lehet [37].

A vér-agy gát penetrációjának előrejelzésében egyre nő a szerepe a molekulák fizikokémiai tulajdonságain alapuló számításoknak, az in silico módszereknek [38]. Így a molekulasúly, az in vitro meghatározott passzív permeabilitás, a P-gp transzporter külcsönhatások, hid- rogéndonor, illetve akceptor tulajdonság, az aromás gyưrúk száma a molekulában, a lipofilicitást jelző $\log \mathrm{P}$ és $\log \mathrm{D}$-értékek, a poláros felszín aránya, a flexibilitás és a pozitív és negatív töltések száma alapján számítógépes kalkulációkat végezhetünk a barriereken való átjutás predikciójára vonatkozóan [39-43]. A meglévő in vitro és in vivo modellekből származó kísérletes adatokat megfelelő algoritmus segítségével használják fel ezek a módszerek molekulakönyvtárak vizsgálatára. Fontos az aktív transzport figyelembevétele (P-gp és BCRP interakció), hiszen ezek a folyamatok jelentősen befolyásolhatják a hidrofób anyagok agyba jutását. Ennek megfelelően kvantitatív szerkezet-hatás összefüggésen alapuló (QSAR) modellt is kifejlesztettek már a P-gp kölcsönhatás predikciójára.

\section{Gyógyszertranszporterek központi idegrendszeri betegségekben}

Klinikai szempontból a vér-agy gátban lévő transzporterek müködésének megértése elengedhetetlen számos neurológiai betegség patomechanizmusának tisztázásához és terápiájának kidolgozásához. A vér-agy gát sérülhet, s így a központi idegrendszer homeosztázisa is felborulhat neurodegeneratív megbetegedések, központi idegrendszeri térfoglaló folyamatok, gyulladásos betegségek, agyi vérellátási zavarok következtében. A vér-agy gát aktívan részt vehet bizonyos kórfolyamatok kialakulásában, mint például Alzheimer-kór [7].

\section{Epilepszia}

Az epilepszia az egyik leggyakoribb neurológiai betegség. Világviszonylatban a populáció 1-2\%-át érinti. Bár számos epilepsziaellenes gyógyszer van forgalomban, a betegek mintegy $40 \%$-a rezisztenciát mutat a farmakoterápiára. Emögött a rezisztencia mögött számos tényező áll. De talán a legfontosabb, a gyógyszermolekulák fokozott transzportja az agyi endothelsejteken. Elsőként Tischler és mtsai írták le 1995-ben, hogy epilepsziás betegeken megnövekedett a multidrug resistance gén (MDRl) expressziója (amelynek terméke az efflux transzporter fehérje, P-gp) [44]. Ennek a folyamatnak a következtében az agyszöveti görcsgócokban az endothelsejtek membránján keresztül megnő a szubsztrátmolekulák visszaáramlása a keringésbe. Tischler eredményeivel összhangban Dombrowski is azt találta, hogy az epilepsziás betegek agyi kapillárisaiban mintegy 134\%kal több MDRl gén expresszálódik, mint a nem epilepsziás alanyokból származó agyi mikroereken [45]. Bizonyítékokat találtak arra is, hogy a P-gp expressziós szintje korrelál a gyógyszerhatással, illetve hatástalansággal mind emberen, mind pedig állatkísérletekben. A P-gp-gátló anyagok adása pedig az antiepileptikumok agyi szintjének megemelkedéséhez, s ezáltal a hatás növekedéshez vezetett [46]. 


\section{Stroke}

Állatkísérletes stroke-modelleken is történtek vizsgálatok a membrántranszporterek szerepére vonatkozóan. Köztudott, hogy az agyi ischaemia következtében a vér-agy gát integritása megbomlik, s jelentősen megnő a gyógyszermolekulák, illetve fehérjék agyszöveti penetrációja. A központi idegrendszerben legfontosabb szerepet játszó P-gp transzporter szerepét Murozono és mtsai mdrl knockout egereken tanulmányozták. Kísérleteik alapján az mdrl génnel nem rendelkező állatokon sokkal kisebb volt az infarktus térfogata középagyi artéria okklúzióját követően [47, 48], mint a vad típusú egereken. Farmakológiai megközelítésben pedig a P-gp inhibitor cyclosporin A alkalmazása drámaian csökkentette az infarktus nagyságát stroke-os állatokon [49]. E megfigyelések alapján logikusnak látszott a P-gp gátlószerek klinikai alkalmazásának bevezetése agyi-ischaemiás állapotokban. Azonban ennek a szándéknak ellentmondott az a tény, hogy a P-gp-gátlás következtében jelentősen megemelkedik a szubsztrát tulajdonsággal rendelkező gyógyszerek bejutása az agyba kontrollálhatatlan központi idegrendszeri mellékhatásokat és toxicitást eredményezve [50].

Újabb kutatások az efflux transzporterek gátlása helyett az uptake transzporterek (OATP) aktiválására helyezik a hangsúlyt a gyógyszerek agyba jutásának elősegítésére, ezáltal elkerülve a nemkívánatos mellékhatásokat [51] (például statinok esetében). A statinok HMG-CoA reduktázgátló antioxidáns neuroprotektív hatású anyagok, amelyek szerepet játszanak az agyi ischaemiás/ hypoxiás károsodások terápiájában. Ronaldson és mtsai kimutatták, hogy a patkány vér-agy gátban a legfontosabb uptake transzporter az oatpla4 [52]. Ennek a transzporternek a hiánya csökkentette az agyi rosuvastatin- és pitavastatinfelvételt [29] knockout egereken.

\section{Alzheimer-kór}

Az Alzheimer-kór az egyik leggyakoribb életkorfüggó neurodegeneratív betegség. Legfontosabb markere a béta-amiloid peptid szenilis plakkokban történő akkumulációja. A folyamat kiváltója ismeretlen, de az utóbbi évek kutatásai az ABC-transzporter fehérjék szerepére is fényt derítettek. Így elsősorben a P-gp-, BCRP-, MRPl- és koleszteroltranszporter fehérjék összefüggéseit mutatták ki az Alzheimer-kór patológiájával, illetve a béta-amiloid plakkok lerakódásával kapcsolatban [53]. Lam és mtsai bizonyították az $\mathrm{A} \beta_{40}$ és $\mathrm{A} \beta_{42}$ P-gp szubsztráttulajdonságát [54]. Ezáltal igazolódott e transzporterek szerepe az amiloid plakkok lerakódásának regulálásában. Több tanulmány igazolta a vér-agy gát endothelsejtjeinek apicalis felszínén a P-gp-expresszió szignifikáns csökkenését a természetes öregedési folyamattal párhuzamosan [5559]. Mindezen megfigyelések alapján megfontolandó stratégia a P-gp-expresszió fokozása, illetve a transzpor- ter aktiválása az időskori Alzheimer-kór megelőzésében. Ezáltal helyreállítható az agyi béta-amiloid-ürítés.

A koleszterintranszporter-protein (ABCAl) szerepe szintén fontos az Alzheimer-kór patológiájában. Ez a transzporter pumpálja ki az agyszövetból a koleszterint, ezáltal csökkentve az arteriosclerosis kockázatát. Az Alzheimer-kórban az amiloid plakkok felhalmozódásában is szerephez jut ennek a transzporternek a múködése, mivel a koleszterin szabályozza a membránfluiditást és a lipidek - amelyekben a béta-amiloid szintézisében szerepet játszó enzimek is találhatók - méretét és megoszlását [60].

Alzheimer-kórban elhunyt betegek hippocampusában fokozott koleszterintranszporter-expressziót mutattak ki. Ez az amiloid plakkok megjelenésével mutatott korrelációt, jelezve, hogy a transzporteraktiválódás a betegség előrehaladott stádiumában jelentkezik [60, 61].

Bár számos kísérleti eredmény igazolta az efflux transzporterek szerepét az Alzheimer-kórban, arra vonatkozóan, hogy a megfigyelt jelenségek okai vagy következményei-e a betegségnek, nincs egyértelmú információ.

\section{Parkinson-kór}

A Parkinson-kór a második leggyakrabban előforduló neurodegeneratív betegség. Patológiájában a nigrostriatalis rendszer dopaminerg neuronjainak pusztulása és a Lewy-testek képződése áll a fő helyen. Bár a betegség oka ismeretlen, igazolták a környezeti neurotoxinok fokozott jelenlétének rizikónövelő hatását. A vér-agy gát detoxikáló hatásának csökkenésében az ott lokalizálódó pumpafehérjék csökkent expressziója, illetve aktivitása áll [62-64]. Az MDRl gén genetikai polimorfizmusát is a Parkinson-kór rizikófaktorai közé sorolják [65, 66].

\section{Amyotrophiás lateralsclerosis}

Az ALS egy lassan progrediáló neurodegeneratív betegség, amely a mozgatóneuronokat támadja meg. Ennek a betegségnek jelenleg nincs hatásos terápiája. Az egyetlen, az amerikai gyógyszerhatóság, a Food and Drug Administration (FDA) által elfogadott gyógyszer a riluzol, amely mind állatkísérletben, mind pedig emberen megnyújta az élettartamot. A sok sikertelen transzlációs próbálkozás (in vitro-ról in vivo-ra, illetve állatról emberre) hátterében a gyógyszerrezisztencia, illetve az alacsony biohasznosíthatóság állhat. ALS-ben megnövekedett efflux transzporterexpresszió figyelhető meg a vér-agy és a vér-liquor gátban, valamint növekszik a transzporterproteinek mennyisége az agyi parenchyma ideg- és gliasejtjein is [67]. Mindez magyarázhatja a széles körü gyógyszerrezisztenciát, és új terápiás stratégiák tervezése előtt nyithatja meg az utat. 


\section{Glioma}

A glioblastoma multiformis, egy extrém agresszív agytumorfajta elkeserítően rossz kimeneteli statisztikával. A jelenleg alkalmazott kemoterápiákra a betegeknek csak mintegy 30-40\%-a reagál. A nagyon rossz statisztikai adatok hátterében az áll, hogy az alkalmazott gyógyszerek nem jutnak el a hatás helyére, mert a vér-agy gátban múködő pumpák, jelen esetben az MRPl, eltávolítják őket. Az előrehaladott gliomákban megnövekedett az MRPl expressziója is [68], ami a transzportergátló szerek terápiás célú fejlesztésének szükségességét és feltételezhető eredményességét veti fel.

\section{HIV-encephalitis}

Mint az közismert, az AIDS (acquired immunodeficiency syndrome) okozója a human immunodeficiency virus (HIV). A vírus az agyba jutva krónikus ideggyulladást, encephalitist okoz. AIDS-es betegek agyi szövetmintáiban a gliasejteken fokozott P-gp-, a vér-agy gátban fokozott MRPl-expressziót találtak $[69,70]$. Ez az eredmény összefüggést mutat azzal, hogy a vírus a citokinek kiválasztását fokozza, amely szintén növeli a transzporterfehérje-expressziót az agyi kapilláris endothelsejteken és az astrocytákon [62, 71]. Ugyanakkor kimutatták, hogy két HIV-ellenes gyógyszer: az atazanavir és a ritonavir növeli a P-gp-expressziót in vitro sejtvonalon és primer human endothelsejt-kultúrán $[72,73]$.

\section{Következtetések}

Az elmúlt évtizedek során végzett kísérletek jelentős eredményeket hoztak a vér-agy gát múködésének, az endothelialis membránfehérjék funkciójának megismerése területén. A központi idegrendszer homeosztázisának védelmében alapvető szerepe van az idegrendszer és a centrális keringés határán elhelyezkedő endothelsejteknek, de rajtuk kívül felismerték a gliasejtek különbözó típusainak, a neuronoknak és a choroid plexust felépítő epithelsejteknek a jelentőségét is. A membránban helyet foglaló transzporter fehérjék a központi idegrendszer védelme mellett annak múködéséhez energiát, tápanyagot is szolgáltatnak, valamint a neurotranszmisszió mechanizmusában és a metabolizmusban is szerepet játszanak.

Számos vizsgálati módszer szolgál annak megállapítására, hogy akár a központi támadáspontú, akár pedig a perifériára ható gyógyszerek transzporter fehérjékkel való kölcsönhatását tanulmányozzák. Az egyszerúbb sejtes rendszerektől kezdve a bonyolultabb in situ, illetve in vivo kísérleti elrendezéseken át jelentős szerepet kapott az utóbbi időben az in silico gyógyszerkutatás is.

A gyógyszerhatások vizsgálata mellett a szervezetben végbemenő fiziológiás és patológiás folyamatok és a transzporter fehérjék összefüggéseit is számos munkacsoport tanulmányozta. A természetes öregedés folyamata során megfigyelhető P-gp-aktivitás-csökkenés és az
Alzheimer-kór patomechanizmusa között korrelációt állapítottak meg. Ugyanakkor más neurodegeneratív betegségben épp ellenkezóleg, a P-gp-t expresszáló gén, az MDRl túlmúködését mutatták ki.

A transzporter fehérjék központi idegrendszerben betöltött meglehetősen komplex szerepét ebben a közleményben megpróbáltuk tömören összefoglalni. A gyógyszer-transzporter kölcsönhatások jobb megismerése, illetve a különböző neurodegeneratív kórképek hátterének mind mélyebb feltárása új farmakoterápiás utakat nyithat meg eddig gyógyíthatatlannak tartott betegségek kezelésében.

Anyagi támogatás: A közlemény megírásához és a kapcsolódó információ gyứjtéséhez a szerzők anyagi támogatásban nem részesültek.

Szerzői munkamegosztás: A cikk elkészítésében E. F. 50, T.-A. Cs., B. E. 25-25\%-ban vett részt. A cikk végleges változatát mindhárom szerző elolvasta és jóváhagyta.

Érdekeltségek: A szerzőknek nincsenek érdekeltségeik.

\section{Köszönetnyilvánítás}

A szerzők ezúton fejezik ki köszönetüket Dr. Krajcsi Péternek a kézirat átolvasásáért, valamint Berkecz Dávidnak és Hesz Margitnak az ábrák elkészítéséért.

\section{Irodalom}

[1] Tsuji, A.: Small molecular drug transfer across the blood-brain barrier via carrier-mediated transport systems. NeuroRx, 2005, 2(1), 54-62.

[2] Terasaki, T., Ohtsuki, S.: Brain-to-blood transporters for endogenous substrates and xenobiotics at the blood-brain barrier: an overview of biology and methodology. NeuroRx, 2005, 2(1), 63-72.

[3] Löscher, W., Potschka, H.: Blood-brain barrier active efflux transporters: ATP-binding cassette gene family. NeuroRx, 2005, 2(1), 86-98.

[4] Sarkadi, B., Homolya, L., Szakács, G., et al.: Human multidrug resistance $\mathrm{ABCB}$ and $\mathrm{ABCG}$ transporters: participation in a chemoimmunity defense system. Physiol. Rev., 2006, 86(4), 1179-1236.

[5] Löscher, W.: Current status and future directions in the pharmacotherapy of epilepsy. Trends Pharmacol. Sci., 2002, 23(3), 113118.

[6] Németh, H., Toldi, J., Vécsei, L.: Role of kynurenines in the central and peripheral nervous systems. Curr. Neurovasc. Res., 2005, 2(3), 249-260.

[7] Pardridge, W. M.: Blood-brain barrier delivery. Drug Discov. Today, 2007, 12(1-2), 54-61.

[8] Danbolt, N. C.: Glutamate uptake. Prog. Neurobiol., 2001, 65(1), 1-105.

[9] Gadea, A., López-Colomé, A. M.: Glial transporters for glutamate, glycine, and GABA III. Glycine transporters. J. Neurosci. Res., 2001, 64(3), 218-222.

[10] Vannucci, S. J., Maher, F., Simpson, I. A.: Glucose transporter proteins in brain: delivery of glucose to neurons and glia. Glia, 1997, 21(1), 2-21. 
[11] Neuwelt, E. A., Bauer, B., Fablke, C., et al.: Engaging neuroscience to advance translational research in brain barrier biology. Nat. Rev. Neurosci., 2011, 12(3), 169-182.

[12] Erikson, K. M., Suber, R., L., Aschner, M.: Glutamate/aspartate transporter (GLAST), taurine transporter and metallothionein mRNA levels are differentially altered in astrocytes exposed to manganese chloride, manganese phosphate or manganese sulfate. Neurotoxicology, 2002, 23(3), 281-288.

[13] Eulenburg, V., Armsen, W., Betz, H., et al.: Glycine transporters: essential regulators of neurotransmission. Trends Biochem. Sci., $2005,30(6), 325-333$.

[14] Inazu, M., Takeda, H., Matsumiya, T.: Expression and functional characterization of the extraneuronal monoamine transporter in normal human astrocytes. J. Neurochem., 2003, 84(1), 43-52.

[15] Kimko, H. C., Cross, J. T., Abernethy, D. R.: Pharmacokinetics and clinical effectiveness of methylphenidate. Clin. Pharmacokinet., 1999, 37(6), 457-470.

[16] Elkashef, A., Vocci, F., Hanson, G., et al.: Pharmacotherapy of methamphetamine addiction: an update. Subst. Abus., 2008, 29(3), 31-49.

[17] Gao, J., Murase, O., Schowen, R. L., et al.: A functional assay for quantitation of the apparent affinities of ligands of P-glycoprotein in Caco-2 cells. Pharm. Res., 2001, 18(2), 171-176.

[18] Moreno-Sanz, G., Barrera, B., Armirotti, A., et al.: Structural determinants of peripheral $O$-arylcarbamate FAAH inhibitors render them dual substrates for Abcbl and Abcg2 and restrict their access to the brain. Pharmacol. Res., 2014, 87, 87-93.

[19] Minocha, M., Khurana, V., Qin, B., et al.: Co-administration strategy to enhance brain accumulation of vandetanib by modulating P-glycoprotein (P-gp/Abcbl) and breast cancer resistance protein (Bcrpl/Abcg2) mediated efflux with $\mathrm{m}$-TOR inhibitors. Int. J. Pharm., 2012, 434(1-2), 306-314.

[20] Hoque, M. T., Kis, O., De Rosa, M. F., et al.: Raltegravir permeability across blood-tissue barriers and the potential role of drug efflux transporters. Antimicrob. Agents Chemother., 2015, $59(5), 2572-2582$.

[21] Hellinger, E., Veszelka, S., Tóth, A. E., et al.: Comparison of brain capillary endothelial cell-based and epithelial (MDCK-MDRl, Caco-2, and VB-Caco-2) cell-based surrogate blood-brain barrier penetration models. Eur. J. Pharm. Biopharm., 2012, 82(2), 340-351.

[22] Thomsen, L. B., Burkhart, A., Moos, T.: A triple culture model of the blood-brain barrier using porcine brain endothelial cells, astrocytes and pericytes. PLoS ONE, 2015, 10(8), e0134765.

[23] Horai, S., Nakagawa, S., Tanaka, K., et al.: Cilostazol strengthens barrier integrity in brain endothelial cells. Cell. Mol. Neurobiol., 2013, 33(2), 291-307.

[24] Sziráki, I., Erdó, F., Trampus, P., et al.: The use of microdialysis techniques in mice to study P-gp function at the blood-brain barrier. J. Biomol. Screen., 2013, 18(4), 430-440.

[25] Murata, M., Tamai, I., Kato, H., et al.: Efflux transport of a new quinolone antibacterial agent, HSR-903, across the blood-brain barrier. J. Pharmacol. Exp. Ther., 1999, 290(1), 51-57.

[26] Takasato, Y., Rapoport, S. I., Smith, Q. R.: An in situ brain perfusion technique to study cerebrovascular transport in the rat. Am. J. Physiol., 1984, 247(3), H484-H493.

[27] Seleman, M., Chapy, H., Cisternino, S., et al.: Impact of P-glycoprotein at the blood-brain barrier on the uptake of heroin and its main metabolites: behavioral effects and consequences on the transcriptional responses and reinforcing properties. Psychopharmacology, 2014, 231(16), 3139-3149.

[28] Miyajima, M., Kusubara, H., Takabashi, K., et al.: Investigation of the effect of active efflux at the blood-brain barrier on the distribution of nonsteroidal aromatase inhibitors in the central nervous system. J. Pharm. Sci., 2013, 102(9), 3309-3319.

[29] Ose, A., Kusubara, H., Endo, C., et al.: Functional characterization of mouse organic anion transporting peptide la4 in the up- take and efflux of drugs across the blood-brain barrier. Drug Metab. Dispos., 2010, 38(1), 168-176.

[30] Ohno, K., Pettigrew, K. D., Rapoport, S. I.: Lower limits of cerebrovascular permeability to nonelectrolytes in the conscious rat. Am. J. Physiol., 1978, 235(3), H299-H307.

[31] Shen, D. D., Artru, A. A., Adkison, K. K.: Principles and applicability of CSF sampling for the assessment of CNS drug delivery and pharmacodynamics. Adv. Drug Deliv. Rev., 2004, 56(12), $1825-1857$.

[32] Walker, M. C., Tong, X., Perry, H., et al.: Comparison of serum, cerebrospinal fluid and brain extracellular fluid pharmacokinetics of lamotrigine. Br. J. Pharmacol., 2000, 130(2), 242-248.

[33] De Lange, E. C., de Boer, A. G., Breimer, D. D.: Methodological issues in microdialysis sampling for pharmacokinetic studies. Adv. Drug Deliv. Rev., 2000, 45(2-3), 125-148.

[34] Hammarlund-Udenaes, M.: The use of microdialysis in CNS drug delivery studies. Pharmacokinetic perspectives and results with analgesics and antiepileptics. Adv. Drug Deliv. Rev., 2000, 45(2-3), 283-294.

[35] Chen, X., Loryan, I., Payan, M., et al.: Effect of transporter inhibition on the distribution of cefadroxil in rat brain. Fluids Barriers CNS, 2014, $11(1), 25$.

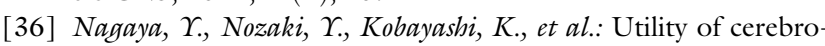
spinal fluid drug concentration as a surrogate for unbound brain concentration in nonhuman primates. Drug Metab. Pharmacokinet., 2014, 29(5), 419-426.

[37] Shen, J., Carcaboso, A. M., Hubbard, K. E., et al.: Compartmentspecific roles of ATP-binding cassette transporters define differential topotecan distribution in brain parenchyma and cerebrospinal fluid. Cancer Res., 2009, 69(14), 5885-5892.

[38] Alavijeh, M. S., Chishty, M., Qaiser, M. Z., et al.: Drug metabolism and pharmacokinetics, the blood-brain barrier, and central nervous system drug discovery. NeuroRx, 2005, 2(4), 554-571.

[39] Mahar Doan, K. M., Humphreys, J. E., Webster, L. O., et al.: Passive permeability and P-glycoprotein-mediated efflux differentiate central nervous system (CNS) and non-CNS marketed drugs. J. Pharmacol. Exp. Ther., 2002, 303(3), 1029-1037.

[40] Van de Waterbeemd, H., Camenisch, G., Folkers, G., et al.: Estimation of blood-brain barrier crossing of drugs using molecular size and shape, and H-bonding descriptors. J. Drug Target., $1998,6(2), 151-165$.

[41] Clark, D. E.: In silico prediction of blood-brain barrier permeation. Drug Discov. Today, 2003, 8(20), 927-933.

[42] Goodwin, J. T., Clark, D. E.: In silico predictions of blood-brain barrier penetration: considerations to "keep in mind". J. Pharmacol. Exp. Ther., 2005, 315(2), 477-483.

[43] Subramanian, G., Kitchen, D. B.: Computational models to predict blood-brain barrier permeation and CNS activity. J. Comput. Aided Mol. Des., 2003, 17(10), 643-664.

[44] Tishler, D. M., Weinberg, K. I., Hinton, D. R., et al.: MDR 1 gene expression in brain of patients with medically intractable epilepsy. Epilepsia, 1995, 36(1), 1-6.

[45] Dombrowski, S. M., Desai, S. Y., Marroni, M., et al.: Overexpression of multiple drug resistance genes in endothelial cells from patients with refractory epilepsy. Epilepsia, 2001, 42(12), 15011506.

[46] Potschka, H., Luna-Munguia, H.: CNS transporters and drug delivery in epilepsy. Curr. Pharm. Des., 2014, 20(10), 1534-1542.

[47] Murozono, M., Matsumoto, S., Okada, S., et al.: Reduction of brain infarction induced by a transient brain ischemia in mdrla knockout mice. Neurochem. Res., 2009, 34(9), 1555-1561.

[48] Ronaldson, P. T., Davis, T. P.: Blood-brain barrier integrity and glial support: mechanisms that can be targeted for novel therapeutic approaches in stroke. Curr. Pharm. Des., 2012, 18(25), 3624-3644.

[49] Murozono, M., Matsumoto, S., Matsumoto, E., et al.: Neuroprotective and neurotoxic effects of cyclosporine $A$ on transient focal 
ischemia in mdrla knockout mice. Eur. J. Pharmacol., 2004 498(1-3), 115-118

[50] Choo, E. F., Kurnik, D., Muszkat, M., et al.: Differential in vivo sensitivity to inhibition of P-glycoprotein located in lymphocytes, testes, and the blood-brain barrier. J. Pharmacol. Exp. Ther., 2006, 317(3), 1012-1018.

[51] Thompson, B. J., Ronaldson, P. T.: Drug delivery to the ischemic brain. Adv. Pharmacol., 2014, 71, 165-202.

[52] Ronaldson, P. T., Davis, T. P.: Targeted drug delivery to treat pain and cerebral hypoxia. Pharmacol. Rev., 2013, 65(1), 291-314.

[53] Abuznait, A. H., Kaddoumi, A.: Role of ABC transporters in the pathogenesis of Alzheimer's disease. ACS Chem. Neurosci., 2012, 3(11), 820-831.

[54] Lam, F. C., Liu, R., Lu, P., et al.: $\beta$-Amyloid efflux mediated by p-glycoprotein. J. Neurochem., 2001, 76(4), 1121-1128.

[55] Kubnke, D., Jedlitschky, G., Grube, M., et al.: MDRl-P-glycoprotein $(A B C B 1)$ mediates transport of Alzheimer's amyloid- $\beta$ peptides - implications for the mechanisms of $A \beta$ clearance at the blood-brain barrier. Brain Pathol., 2007, 17(4), 347-353.

[56] Cirrito, J. R., Deane, R., Fagan, A. M., et al.: P-glycoprotein deficiency at the blood-brain barrier increases amyloid- $\beta$ deposition in an Alzheimer disease mouse model. J. Clin. Invest., 2005, 115(11), 3285-3290.

[57] Vogelgesang, S., Cascorbi, I., Schroeder, E., et al.: Deposition of Alzheimer's $\beta$-amyloid is inversely correlated with P-glycoprotein expression in the brains of elderly non-demented humans. Pharmacogenetics, 2002, 12(7), 535-541.

[58] Vogelgesang, S., Warzok, R. W., Cascorbi, I., et al.: The role of Pglycoprotein in cerebral amyloid angiopathy; implications for the early pathogenesis of Alzheimer's disease. Curr. Alzheimer Res., $2004,1(2), 121-125$

[59] Silverberg, G. D., Messier, A. A., Miller, M. C., et al.: Amyloid efflux transporter expression at the blood-brain barrier declines in normal aging. J. Neuropathol. Exp. Neurol., 2010, 69(10), 1034-1043.

[60] Akram, A., Schmeidler, J., Katsel, P., et al.: Increased expression of cholesterol transporter $A B C A 1$ is highly correlated with severity of dementia in AD hippocampus. Brain Res., 2010, 1318, 167-177.

[61] Kim, W. S., Bhatia, S., Elliott, D. A., et al.: Increased ATP-binding cassette transporter Al expression in Alzheimer's disease hippocampal neurons. J. Alzheimers Dis., 2010, 21(1), 193-205.

[62] Qosa, H., Miller, D. S., Pasinelli, P., et al.: Regulation of ABC efflux transporters at blood-brain barrier in health and neurological disorders. Brain Res., 2015, 1628, 298-316.
[63] Kalia, L. V., Lang, A. E.: Parkinson's disease. Lancet, 2015, 386(9996), 896-912.

[64] Westerlund, M., Belin, A. C., Olson, L., et al.: Expression of multidrug resistance 1 mRNA in human and rodent tissues: reduced levels in Parkinson patients. Cell Tissue Res., 2008, 334(2), 179185.

[65] Liu, X., Ma, T., Qu, B., et al.: Pesticide-induced gene mutations and Parkinson disease risk: a meta-analysis. Genet. Test. Mol. Biomarkers, 2013, 17(11), 826-832.

[66] Zschiedrich, K., König, I. R., Brüggemann, N., et al.: MDRl variants and risk of Parkinson disease. Association with pesticide exposure? J. Neurol., 2009, 256(1), 115-120.

[67] Jablonski, M., Miller, D. S., Pasinelli, P., et al.: ABC transporterdriven pharmacoresistance in Amyotrophic Lateral Sclerosis. Brain Res., 2015, 1607, 1-14.

[68] Tivnan, A., Zakaria, Z., O'Leary, C., et al.: Inhibition of multidrug resistance protein 1 (MRPl) improves chemotherapy drug response in primary and recurrent glioblastoma multiforme. Front. Neurosci., 2015, 9, 218.

[69] Hayashi, M., Sakata, M., Takeda, T., et al.: Hypoxia up-regulates hypoxia-inducible factor- $1 \alpha$ expression through RhoA activation in trophoblast cells. J. Clin. Endocrinol. Metab., 2005, 90(3), 1712-1719.

[70] Hayashi, K., Pu, H., Tian, J., et al.: HIV-Tat protein induces Pglycoprotein expression in brain microvascular endothelial cells. J. Neurochem., 2005, 93(5), 1231-1241.

[71] Ronaldson, P. T., Bendayan, R.: HIV-1 viral envelope glycoprotein gp120 triggers an inflammatory response in cultured rat astrocytes and regulates the functional expression of P-glycoprotein. Mol. Pharmacol., 2006, 70(3), 1087-1098.

[72] Chan, G. N., Patel, R., Cummins, C. L., et al.: Induction of Pglycoprotein by antiretroviral drugs in human brain microvessel endothelial cells. Antimicrob. Agents Chemother., 2013, 57(9), 4481-4488.

[73] Zastre, J. A., Chan, G. N., Ronaldson, P. T., et al.: Up-regulation of P-glycoprotein by HIV protease inhibitors in a human brain microvessel endothelial cell line. J. Neurosci. Res., 2009, 87(4), 1023-1036. 